\title{
Percepções de gestores de incubadoras e empresas incubadas sobre o processo de incubação
}

A criação, desenvolvimento e manutenção de pequenas empresas frente a um cenário competitivo geram instabilidades e incertezas. Para que isso não ocorra, as empresas buscam estratégias que auxiliem sua estabilidade nesse mercado. As incubadoras de empresas colocam à disposição essas garantias oferecendo serviços que amparem as incubadoras. A pesquisa teve como objetivo identificar as percepções de gestores de incubadoras e incubadas sobre o processo de incubação. Foi realizada pesquisa de natureza qualitativa de caráter descritivo. A coleta de dados foi por meio de questionário semiestruturado respondidos por 4 gestores de incubadoras e 11 gestores de empresas incubadas. A análise de dados foi realizada de maneira interpretativa. Os resultados obtidos indicam que todas as incubadoras possuem gestão da performance, oferecem serviços base, técnicos, de gestão, estratégicos e realizam seleção de empresas. Os fatores percebidos pelas incubadoras que impactam na performance das incubadas são qualificação e network. As incubadas são empresas de tecnologia e estão há pouco tempo no processo de incubação, sendo que o motivo que levou a participação no processo é de usufruir do espaço alugado e de outros recursos. As incubadas citam que para que haja o sucesso nas ações com as universidades é necessário qualificação e network.

Palavras-chave: Incubadoras; Incubadas; Empreendedorismo; Inovação.

\section{Perceptions of managers of incubators and incubated companies on the incubation process}

Creation, development and maintenance of small businesses facing a competitive environment generate instabilities and uncertainties. To avoid it, companies seek strategies which helps stability in this market. Business incubators provide guarantees providing services that support the incubators. The research aimed to identify the perceptions of incubator managers and incubated on the incubation process. The research had a qualitative and descriptive character. Data collection was through semi-structured questionnaire answered by 4 managers of incubators and 11 managers of incubated companies. Data analysis was performed interpretative way. The results indicates that all incubators have performance management, provide basic services, technical, management, strategic and perform selection of companies. Factors perceived by incubators that impact the performance of the incubated are skills and network. The incubated are technology companies and are recently in the incubation process, and the reason that led to participation in the process is to use the leased space and other resources. The incubated mention that to have sucess in this process is necessary trainning and network.

Keywords: Incubators; Incubated; Entrepreneurship; Innovation

\section{Topic: Empreendedorismo}

Reviewed anonymously in the process of blind peer.

Gisele Costa Rabello

Faculdade Meridional, Brasil

http://lattes.cnpq.br/6422092867699305

gisele.rabello@hotmail.com

Gabriele Rodrigues

Faculdade Meridional, Brasil

http://lattes.cnpq.br/6682300207748546

gabrielerodrigues@hotmail.com

Eliana Andréa Severo

Universidade Potiguar, Brasil

http://lattes.cnpq.br/0272640518459010

elianasevero2@hotmail.com
Received: 18/01/2017

Approved: 18/03/2017

Amilton Rodrigo De Quadros Martins

Faculdade Meridional, Brasil

http://lattes.cnpq.br/1924119407995975

si@imed.edu.br
Referencing this:

REBELLO, G. C.; RODRIGUES, G.; SEVERO, E. A.; MARTINS, A. R. Q.. Percepções de gestores de incubadoras e empresas incubadas sobre o processo de incubação. Revista Brasileira de Administração Científica, v.8, n.1, p.190-203, 2017. DOI: http://doi.org/10.6008/SPC2179-684X.2017.001.0015 


\section{INTRODUÇÃO}

O empreendedorismo impulsiona o crescimento econômico da sociedade através da criação de novas empresas que podem gerar novas tecnologias, produtos, serviços e empregos. Porém, a abertura das micro e pequenas empresas possui algumas adversidades, como falta de experiência em gestão, falta de capital e pouco conhecimento sobre o mercado. Todos esses fatores tornam arriscado investir em um empreendimento e muitos não chegam a completar um ano de funcionamento (SERRA et al., 2011).

As pequenas empresas de alta tecnologia possuem um índice de fracassos maior do que outros tipos de empresas, pois o produto e serviço oferecido é inovador, necessita de mais investimentos e corre um alto risco de não ser aceito pelo mercado. Por isso, é importante oferecer um ambiente, como as incubadoras empresariais, que favoreça a elaboração de projetos tecnológicos e que aumente suas chances de sucesso (HSRICH et al., 2004).

No Brasil, as incubadoras, em especial às ligadas a instituições de ensino superior (IES), são favoráveis a formação desse ambiente, pois coloca à disposição das novas empresas instalações físicas, facilidades e serviços e, ainda, oferecem às empresas incubadas suporte técnico-gerencial que gera oportunidades para compartilhar experiências e network (ENGELMAN et al., 2011). Dessa forma, essa pesquisa tem como objetivo identificar as percepções de gestores de incubadoras e incubadas sobre o processo de incubação. Esta análise foi realizada a partir do levantamento de informações sobre as percepções dos gestores de 4 incubadoras e a percepção dos gestores de 11 empresas incubadas. Essa pesquisa está dividida em sete seções, incluindo a introdução, seguido do referencial teórico, metodologia, análise e discussão dos resultados, considerações finais e referências.

\section{REVISÃO TEÓRICA}

\section{Empreendedorismo}

A base teórica da presente pesquisa está dividida nos seguintes tópicos: empreendedorismo, inovação, incubadoras e incubadas. Primeiramente, será abordado conceitos de empreendedorismo e inovação e, por fim, será apresentado o contexto das incubadoras e incubadas. Considerando um contexto em que os conceitos e sentidos do trabalho encontram-se diferenciados, especialmente devido ao cenário extremamente competitivo, observa-se uma mudança nos vínculos de trabalhos e, com isso, o aumento de número de pessoas que abrem seu próprio negócio tem ganhado espaço (MELO et al., 2010).

O conceito de empreendedorismo já foi abordado de diferentes formas e abrange desde as questões econômicas quanto às questões sociais (BAÊTA et al., 2006). Para Morris (1998), o empreendedorismo não se dá somente pela abertura de negócios de pequeno porte, mas também para a orientação ao desenvolvimento dos negócios, não adiantando ser de pequeno porte e não apresentar características para a inovação dentro de uma gama de produtos e serviços. O empreendedorismo, ainda segundo o autor, é considerado um construto universal e pode ser utilizado por qualquer pessoa, organização ou país. Conforme Morris (1998), há muitas diferenças nas características dos pequenos negócios que podem ser entendidas 
como diferentes dos demais negócios, mas não são compreendidos como empreendedores, as quais podem ser identificadas no quadro 1.

Quadro 1: Diferenças entre pequenos negócios e negócios empreendedores.

\begin{tabular}{|c|c|}
\hline Características dos pequenos negócios & Caraterísticas de negócios empreendedores \\
\hline Estável & Instável \\
\hline Orientado ao status quo & Orientada à mudança \\
\hline Não agressivo & Agressivo \\
\hline Orientado à sociedade & Orientada ao mercado \\
\hline Interação entre atividades pessoais e profissionais & Clareza das atividades pessoais e profissionais \\
\hline Envolvimento de pessoas da família & Envolvimento de profissionais \\
\hline Informal & Formal \\
\hline Tático & Estratégico \\
\hline Orientado ao presente & Orientado ao futuro \\
\hline $\begin{array}{l}\text { Preferência pelo baixo risco/pouco retorno das } \\
\text { atividades }\end{array}$ & Preferência pelo alto risco/alto retorno das atividades \\
\hline Orientado ao ambiente interno & Orientado ao ambiente externo \\
\hline Número fixo de funcionários & $\begin{array}{l}\begin{array}{l}\text { Crescimento do número de funcionários com alto potencial para } \\
\text { conflitos }\end{array}\end{array}$ \\
\hline Nível de necessidade de recursos & Crescente necessidade de recursos com escassez de fluxo de caixa \\
\hline Guiada pelos recursos & Guiada pelas oportunidades \\
\hline $\begin{array}{l}\text { Preocupação em obtenção de lucro, substituição de } \\
\text { renda }\end{array}$ & Preocupação com o crescimento e valorização do negócio \\
\hline
\end{tabular}

Fonte: Morris (1998).

Diversas evidências têm demonstrado que o empreendedorismo é fundamental para a sobrevivência do negócio, devido às intensas mudanças, aumento da competitividade, valores sociais, necessidades dos consumidores, mudanças de tecnologias, entre outros (MORRIS, 1998). Conforme descreve Morris (1998), o empreendedorismo pode ser de diferentes formas, como: criação de riqueza, criação de empresas, criação de inovação, criação de mudança, criação de empregos, criação de valor e criação de crescimento. Por isso, percebe-se uma grande importância do empreendedorismo para o desenvolvimento econômico que, consequentemente, auxilia nas mudanças dos cenários para a promoção das inovações em diversas regiões e culturas (DORNELAS, 2004).

Nesse contexto, percebe-se que o empreendedor é percebido como peça fundamental para esse desenvolvimento, o qual Schumpeter (1959) define que para ser empreendedor de sucesso deve-se ter competências comportamentais além de competências técnicas. 0 empreendedor tem como papel reformar ou revolucionar o padrão do que se produz de possibilidades ainda não testadas, gerando assim novas mercadorias ou a produção de algo que já exista, mas de uma forma diferente, o que gerará uma nova indústria (RAUPP et al., 2006). Com isso, o empreendedorismo tem sido fundamental para fomentar a inovação (DRUCKER, 1985). Neste contexto, entende-se que as interfaces entre a tecnologia e a economia possibilitam que as inovações mantenham o desenvolvimento econômico e a capacidade competitiva das organizações, melhorando o desempenho do setor (SCHUMPETER, 1959).

\section{Inovação}

A palavra inovação é considerada muito polissêmica e consensual e tem se mantido estreitamente ligada a preocupações de cunho econômico como, por exemplo, a competitividade e as pressões de mercado (ANDRADE, 2005). As inovações são consequências das mudanças que criam melhorias de desempenho das 
atividades econômicas do mercado e podem intervir em processos, serviços ou, ainda, sobre a gestão das organizações.

A inovação pode ser classificada em quatro categorias distintas, segundo o Manual de Oslo como sendo: de produto, de processo, de marketing e organizacional. Os tipos de inovação de produto e processo são as categorias mais importantes para a Teoria Schumpeteriana, por possibilitarem mudanças relevantes no processo de produção (BRASIL et al., 2011). Ainda, a inovação pode ser classificada como radical ou incremental, quanto a sua dimensão. E, também, pode ser dividida em inovação aberta ou inovação fechada (LEIFER et al., 2000; CHESBROUGH, 2006)

Ainda referente a essas classificações, encontra-se a inovação tecnológica. Segundo Betz (1993, citado por RIBEIRO et al., 2005) a inovação tecnológica é definida como processo de criação, desenvolvimento e inserção de produtos e serviços no mercado através da incorporação de diferentes e novas tecnologias. Essa categoria pode ser um meio de geração de empregos que gerará riquezas e outras formas de crescimento econômico na região em que essas empresas estão instaladas, com bases tecnológicas (LACERDA et al., 2001).

Consoante a essa realidade, percebe-se que a atitude das empresas presentes nesses contextos é altamente ativa, pois quanto mais se inova em produtos ou serviços, maior será a capacidade da empresa gerar lucros e aumentar a competitividade do mercado. Como define Schumpeter (1959), a capacidade de inovação e resistência à concorrência é extremamente maior em grandes empresas do que empresas de pequeno porte. Segundo Lanzillotti (2003), baseado nos princípios de Schumpeter da destruição criativa, só há inovação quando se cria algum valor a um produto ou serviço, sendo que os produtos anteriores a essa inovação são totalmente eliminados do mercado e tornam-se obsoletos.

Perante o exposto, entende-se que é relevante a existência de incubadoras para nortear as pequenas empresas incubadas que querem iniciar suas atividades quanto ao mercado, afim de garantir melhor desempenho e aumentar a competitividade, desafiando as empresas incubadas à inovação e à criatividade (BAÊTA et al., 2006).

\section{Incubadoras e Incubadas}

As incubadoras de empresas oferecem infraestrutura física e gerencial para indivíduos empreendedores que possuem ideias promissoras, para transformá-las em negócios reais e sustentáveis (FINER et al., 2002). Observa-se que além de oferecerem espaço físico elas também fornecem acesso a fontes de networking, recursos financeiros, tecnológicos e organizacionais (KILCREASE, 2011).

Incubadoras também podem ser definidas como mecanismos que originam ambientes de suporte para iniciativas empreendedoras e as auxiliam a aumentar suas chances de sobrevivência (SOMSUK et al., 2012). A ANPROTEC (2015) conceitua incubadoras de empresas e parques tecnológicos como entidades promotoras de empreendimentos inovadores, sendo objetivo da incubadora oferecer suporte aos empreendedores para que eles tenham condições de desenvolver ideias inovadoras e consigam concretizá- 
las em empreendimentos. Para atingir esses objetivos, ela deve oferecer infraestrutura e suporte gerencial, com orientações aos gestores ligadas às questões essenciais ao desenvolvimento da empresa.

Para atingirem seus propósitos, as incubadoras possuem três processos chaves: seleção: objetiva identificar projetos que possuam condições de desenvolvimento; suporte gerencial; e graduação: procedimentos que identificam as empresas incubadas que se encontram preparadas para integrar o mercado, sem interferência da incubadora (RATINHO et al., 2010; BRUNEEL et al., 2012).

Um importante fator que contribui para o sucesso das empresas incubadas é o fácil acesso ao conhecimento promovido pelas incubadoras (BOLLINGTOFT, 2012). O conhecimento é uma importante oportunidade dada às empresas incubadas (QIAN et al., 2011), pois agrega valor às suas propostas (BRUNEEL et al., 2012) e isto é percebido, na transferência do conhecimento das IES para as empresas já graduadas (SCHWARTZ et al., 2008).

As incubadoras podem ser consideradas um dos mais eficazes instrumentos no fomento de empresas inovadoras e na criação de empregos baseados no conhecimento (AHMAD et al, 2011), e devem disponibilizar que novos conhecimentos e o acesso às suas fontes sejam disponíveis às empresas incubadas (KILCREASE, 2011). Para Somsuk et al. (2012), incubadoras de empresas são projetadas para preencher um gap de conhecimento existente em empreendimentos em seus estágios iniciais, como forma de torná-los negócios exequíveis.

Algumas das principais razões para a criação de incubadoras brasileiras são a incitação ao empreendedorismo, a transformação de pesquisas em produtos e serviços, o desenvolvimento do potencial tecnológico de determinadas regiões e o encorajamento à colaboração entre universidade e sociedade (MORAIS, 1997; BRASIL, 2000). Em 1982, já haviam sido inauguradas as primeiras incubadoras brasileiras, porém apenas em 1987, após a realização do Seminário Internacional de Parques Tecnológicos no estado do Rio de Janeiro, elas foram consolidadas como forma de incentivo à produção tecnológica. Ainda em 1987, surgia a ANPROTEC, que representava as incubadoras de empresas e todos os empreendimentos que utilizassem do processo de incubação como forma de gerar inovação (ANPROTEC, 2007; GUIMARÃES et al., 1999; BRASIL, 2000).

A partir do ano de 1993, aumentou o número de parques científicos e incubadoras de empresas por todo país. Esta situação ocorreu principalmente decorrente da ideia de que as empresas brasileiras possuíam a necessidade de tornarem-se mais competitivas e, desta forma, era preciso estimular a capacidade de inovação tecnológica (ANPROTEC, 2007; GUIMARÃES et al., 1999; BRASIL, 2000).

Conforme estudo realizado pela ANPROTEC e Ministério de Ciência, Tecnologia e Inovação no ano de 2011, o Brasil possui 384 incubadoras operando, que abrigam 2.640 empresas e gerando 16.394 postos de trabalho. Destas incubadoras, já se encontram graduados 2.509 empreendimentos, com faturamento de R\$4,1bi e geração de 29.205 empregos. Este estudo também apontou que $98 \%$ das empresas incubadas inovam, sendo que $28 \%$ com foco no âmbito local, $55 \%$ no nacional e $15 \%$ no mundial (ANPROTEC, 2015). 


\section{METODOLOGIA}

Conforme Prodanov et al. (2013), a metodologia se define pela aplicação de técnicas que deverão ser avaliadas para a construção e desenvolvimento do conhecimento, a fim de garantir que sua validade e finalidade sejam comprovados para a sociedade. Conforme Gibbs (2009), para que haja efetividade na metodologia da pesquisa, o método escolhido deve estar de acordo com o que se pretende atingir como objetivo, sendo que as limitações dos métodos devem ser observadas.

Para que seja possível atingir os objetivos propostos da seguinte pesquisa, classifica-se como pesquisa empírica, pois foi realizada diretamente nos locais onde os fenômenos ocorrem. A pesquisa é de natureza qualitativa, pois permite maior compreensão do fenômeno. Ainda, tem caráter descritivo, pois descreve os fenômenos presentes nas organizações estudadas, sendo que Gil (2002) considera que essas pesquisas são as mais solicitadas por organizações como instituições educacionais, empresas comerciais, partidos políticos, entre outros.

O delineamento da pesquisa se deu de forma documental, através do levantamento de informações através de um questionário semiestruturado. A partir dessa coleta, foi possível identificar as percepções dos gestores de empresas incubadas e das incubadoras sobre o processo de incubação. Foram mapeadas 11 incubadoras de Instituições de Ensino Superior (IES), entre elas universidades, centros universitários e faculdades de distintas regiões do estado do Rio Grande do Sul. A partir dessa seleção, foram identificadas através de busca pelos sites das IES quais as empresas estão incubadas atualmente nas incubadoras mapeadas. Neste sentido, foram identificadas um total de 67 empresas incubadas das 11 incubadoras selecionadas. Ressalta-se que a escolha das 11 IES foi por conveniência, pois são incubadoras que os pesquisadores desse estudo conseguiriam os contatos de forma mais próxima.

Para a coleta de dados, foi utilizado o questionário da pesquisa de Marques (2005), adaptado a realidade brasileira. $\mathrm{O}$ questionário era dividido em questões para os gestores das incubadoras e para os gestores das empresas incubadas. O questionário direcionado aos gestores das incubadoras apresentou um total de 16 questões, entre elas questões abertas e fechadas. O questionário direcionado aos gestores das empresas incubadas apresentou um total de 14 questões, também, abertas e fechadas. Os questionários foram enviados no formato digital (Google Docs) aos e-mails dos gestores.

O envio do questionário e o retorno das respostas ocorreram durante o mês de novembro de 2015. Não participaram desta pesquisa as empresas que já haviam finalizado o processo de incubação. Ao todo, 4 incubadoras e 11 incubadas responderam os questionários, totalizando a amostra da pesquisa. Por fim, a análise dos dados foi feita de forma interpretativa.

\section{RESULTADOS E DISCUSSÃO}

\section{Incubadoras}

Primeiramente, serão apresentados os resultados das incubadoras e, na sequência, os resultados das incubadas. A análise será feita a partir de cada questão do questionário elaborado para essa pesquisa. 0 
questionário desenvolvido para os gestores de incubadoras obteve 4 respondentes, com considerável distância temporal entre suas datas de fundação, considerando que uma delas iniciou suas atividades no ano de 1998 e outra possui um recente início no ano de 2011.

Entre as respondentes, 3 delas são instituições privadas sem fins lucrativos, 1 encontra-se sediada em um parque tecnológico, outra integra um parque de ciência e tecnologia, enquanto duas pertencem a universidades/faculdades. Em sua maioria, as incubadoras encontram-se vinculadas ou próximas de universidades, faculdades, laboratórios e institutos de pesquisa e, desta forma, obtêm benefícios do conhecimento e outros recursos oferecidos por estas instituições (SERRA et al., 2011).

Todas as incubadoras pesquisadas afirmaram serem submetidas a avaliações de desempenho. É necessário e importante realizar avaliações de gestão de performance das incubadoras (MARQUES, 2005), afinal, elas são organizações de serviços e devem medir-se conforme dois padrões básicos: desenhar os serviços de valor e acrescentar o que as empresas necessitam; disponibilizar tais serviços consistentemente. Desta forma, as incubadoras são capazes de acrescentar valor as empresas incubadas (WIGGINS et al., 2003).

A incubadora 1 afirmou ter sua avaliação baseada em produtividade, conhecimento, ética e qualificação. A incubadora 2, possui uma avaliação de desempenho anual realizada pelos recursos humanos da universidade a qual pertence e nessa avaliação são considerados os seguintes itens: competências técnicas, funcionais, específicas e competências comportamentais. Também são realizadas duas reuniões anuais do conselho deliberativo da incubadora onde são apresentados e avaliados os resultados obtidos e as estratégias adotadas. A incubadora 3 realiza acompanhamento semestral de indicadores do parque tecnológico e da incubadora. A incubadora 4 avalia metas relacionadas ao atingimento de números de projetos, faturamento e empregos gerados, juntamente com o controle orçamentário.

Considerando que a ANPROTEC (2007) define incubadora como um local criado para abrigar empresas e oferecer infraestrutura, apoio gerencial e técnico como serviços de recepção e secretaria, salas de reunião, Internet, telefone, e uma gama de serviços, foi questionado sobre os serviços que as incubadoras acreditam oferecer a suas incubadas. Para isso, os serviços foram divididos em quatro setores: base, técnicos, gestão e estratégicos.

Sobre os serviços de base, todos os gestores de incubadoras afirmaram oferecer os mesmos serviços, sendo eles: infraestrutura física, limpeza, telecomunicações e acesso à web. Nos serviços técnicos, informaram acesso a P\&D (pesquisa e desenvolvimento) da universidade ou faculdade. As Incubadoras 2 e 4, também acrescentaram consultoria técnica. Em serviços de gestão, foi respondido: contabilidade/finanças, gestão estratégica, vendas/marketing, e as Incubadoras 3 e 4 incluíram assessoria jurídica em suas respostas. Referente aos serviços estratégicos, todos informaram acesso a informação sobre fontes de financiamento. A incubadora 2 acrescentou acesso a legislação e formação técnica dos recursos humanos. A incubadora 3, incluiu formação técnica dos recursos humanos, apoios nas relações internacionais e acordos entre empresas. E a incubadora 4, afirmou também apoiar nas negociações bancárias.

A pesquisa também abordou as atividades da direção da incubadora com caráter de rotina e o tempo dedicado (em média) por semana para as atividades. Notou-se que as incubadoras dedicam cerca de 3 a 4 
vezes por semana, para a promoção da incubadora e atração de novas empresas, que nem todas são responsáveis pela manutenção das instalações, que gastam cerca de 1 a 2 vezes por semana com promoção de serviço e obtenção de financiamentos, de 3 a 4 vezes por semana para fomentar cooperação com a universidade/faculdade, e a frequência semanal para o fomento de cooperação entre as empresas sediadas e fornecer serviços de gestão estratégica e funcional é diferente entre as incubadoras. Nos itens referentes ao apoio legal no que se refere à transferência do conhecimento/tecnologia e apoio legal na comercialização da tecnologia (patentes), não são aplicáveis em duas incubadoras e nas que existem são utilizadas cerca de 1 a 2 vezes por semana.

Sobre as incubadas pertencentes às incubadoras pesquisadas, são empresas spin-off da universidade/faculdade ou empresas novas de iniciativa individual ou dos sócios. Considera-se uma spin-off uma empresa nova que surge de uma organização mãe (COOPER, 1971). Como critérios de seleção das empresas candidatas à instalação nas incubadoras repetem-se os itens: grau de inovação o produto ou serviço, possibilidade de mercado para o empreendimento, capacidade empreendedora dos membros da empresa e viabilidade técnica e econômica do projeto.

As principais dificuldades no processo seletivo das empresas candidatas à instalação na incubadora são a falta de conhecimento sobre a incubadora, candidatos com pouco conhecimento em gestão, atração de empreendedores diferenciados, projetos com maior grau de inovação e empresas que não desenvolvem adequadamente seu modelo/plano de negócios.

As ações desenvolvidas para fomentar a cooperação entre as empresas sediadas na incubadora e a universidade apresentadas foram reuniões mensais, participação em eventos, eventos periódicos de networking, workshops com pesquisadores, apresentação de investidores, banco de oportunidades, cursos, treinamentos com empresários da comunidade em geral. Considerando que as incubadoras de empresas oferecem infraestrutura física e gerencial para pessoas com ideias de negócios empreendedores e promissoras (FINER et al., 2002), procurou-se medir a partir da visão das incubadoras a importância dos serviços prestados para o sucesso das empresas incubadas.

Tabela 1: Serviços prestados pela incubadora para o sucesso do negócio da empresa incubada conforme o grau de importância percebido

\begin{tabular}{|c|c|c|c|c|c|}
\hline & $\begin{array}{c}1 \\
\text { Nada } \\
\text { importante }\end{array}$ & 2 & 3 & 4 & $\begin{array}{c}5 \\
\text { Muito } \\
\text { Importante } \\
\end{array}$ \\
\hline $\begin{array}{l}\text { Infraestrutura (salas individuais e coletivas, laboratórios, auditório, biblioteca, salas } \\
\text { de reunião, recepção, copa, cozinha, estacionamento) }\end{array}$ & 0 & 0 & 1 & 2 & 1 \\
\hline Serviços básicos (telefonia e acesso à web, recepcionista, segurança, xerox) & 0 & 0 & 2 & 2 & 0 \\
\hline $\begin{array}{l}\text { Assessoria (gerencial, contábil, jurídica, apuração e controle de custo, gestão } \\
\text { financeira, comercialização, exportação) }\end{array}$ & 0 & 0 & 0 & 2 & 2 \\
\hline Qualificação (treinamento, cursos, assinaturas de revistas, jornais e publicações) & 0 & 0 & 0 & 1 & 3 \\
\hline $\begin{array}{l}\text { Network (contatos de nível com entidades governamentais e investidores, } \\
\text { participação em eventos de divulgação das empresas, fóruns) }\end{array}$ & 0 & 0 & 0 & 0 & 4 \\
\hline
\end{tabular}

Segundo os dados compilados na tabela 1 , dentre seus serviços prestados para as empresas incubadas, os que são considerados mais importantes para a performance das incubadas são os serviços referentes a qualificação (treinamento, cursos, assinaturas de revistas, jornais e publicações) e network (contatos de nível com entidades governamentais e investidores, participação em eventos de divulgação das 
empresas, fóruns), não sendo apontado nenhum dos serviços como não importante. Os itens de infraestrutura e serviços básicos ficaram como neutros.

\section{Incubadas}

As perguntas do questionário mapearam as características das 11 incubadas. A primeira questão teve como objetivo identificar os nomes das empresas, os quais não serão abertos nesta pesquisa. Ainda, como caracterização das incubadas, identificou-se que 4 empresas foram fundadas no ano de 2014, 3 no ano de 2015, 1 no ano de 2013, 1 no ano de 2012, 1 no ano de 2011 e 1 no ano de 2009.

Percebe-se que a maioria das incubadas ainda estão em um processo muito recente de abertura e, também, $100 \%$ das empresas incubadas tiveram suas origens devido à iniciativa individual ou dos sócios. No estudo realizado por Marques (2005), identificou que $81 \%$ das empresas incubadas analisadas eram empresas novas e também foram abertas por iniciativa individual dos sócios. Percebe-se que nas respostas das incubadoras foi identificado uma empresa spin off, o que não confere com as informações preenchidas pelas incubadas.

O tempo em que as incubadas estão nas incubadoras também foi foco da presente pesquisa. Identificou-se que 4 das 11 incubadas estão nas incubadoras de 1 a 2 anos, 4 estão há menos de 1 ano, 2 estão de 2 a 3 anos e 1 está há mais de 3 anos. Ou seja, 73\% das incubadas está há pouco tempo instaladas nas incubadoras. Quanto ao número de funcionários, somente 2 incubadas possuem de 4 a 10 funcionários. Já a maioria das incubadas, total de 9, possuem até 3 funcionários. Esses números são muito semelhantes aos resultados dos estudos de Marques (2005), o qual 39,2\% das incubadas possuem até 3 funcionários e $49,4 \%$ possuem de 4 a 10 funcionários.

No que se refere à atividade da empresa, 5 incubadas são de desenvolvimento de software ou hardware, 2 de design e construção de protótipos e as outras 4 incubadas são de serviços de consultoria, desenvolvimento de jogos e realidade virtual, serviços de $\mathrm{TI}$ e venda/distribuição. Observa-se aqui uma tendência às áreas de tecnologia de informação, corroborando com o estudo realizado por Marques (2005) que também identificou que $48,1 \%$ das empresas incubadas eram do setor de tecnologia de informação.

Quanto a questão sobre as ações de cooperação existentes entre as empresas e a universidade/faculdade, houve maior frequência das ações de acesso das empresas aos serviços de informação e informática da universidade/faculdade, sendo que 7 das 11 incubadas citaram esse tipo de ação seguido das ações de acesso das empresas aos equipamentos e material de laboratório da universidade/faculdade. As demais ações foram citadas com pouca ou nenhuma frequência. É importante ressaltar também que 1 incubada não realiza nenhum tipo das ações citadas e 1 incubada não respondeu a essa questão.

As razões para o não estabelecimento de ações de cooperação com a universidade/faculdade também foram identificadas nesta pesquisa. Das 11 incubadas, 4 delas consideraram a falta de oportunidade, 3 citaram nenhuma razão, 2 consideraram que o assunto nunca foi considerado e 1 citou que não há interesse da universidade/faculdade pelo projeto realizado pela incubada. Com isso, é importante ressaltar que deve 
haver um alinhamento entre o interesse da comunidade, nesse caso as empresas incubadas, e os programas oferecidos pela universidade/faculdade (BARBOSA et al., 2013).

Os fatores que motivaram a instalação da sua empresa na incubadora também foi parte integrante do questionário. Muitas das alternativas foram selecionadas, com exceção da alternativa 'obter prestígio e imagem da entidade promotora da incubadora'. A alternativa 'usufruir do espaço alugado e demais ajudas' foi citada por todas as 11 incubadas, seguida das alternativas 'usufruir de acesso a conhecimentos e contatos na região e área de atuação' e 'possibilidade de contatos com outras empresas'. A demais alternativas foram citadas 7 vezes até 1 vez. Consoante a esses resultados, destaca-se o estudo de Salvador et al. (2009) que identificou que a infraestrutura fornecida pela incubadora é o ponto mais atrativo para motivação a procura por incubadoras.

Quando questionados a respeito dos resultados finais das ações de cooperação com a universidade/faculdade, identificou que as consultorias técnicas, introdução de melhorias nos produtos e/ou processos existentes e formação de recursos humanos (aprendizagem) são resultados mais evidentes encontrados pelas incubadas. As demais alternativas foram marcadas, mas com pouca ou nenhuma frequência.

Foi questionado também quais as principais formas de transferência do conhecimento/tecnologia resultantes das ações de cooperação. A alternativa mais citada foi a de aquisição/venda, citada por 4 incubadas, e ainda, 3 citaram o contrato de licença. Neste contexto, ainda foi questionado sobre os serviços prestados pela incubadora para o sucesso do negócio da empresa incubada.

Tabela 2: Serviços prestados pela incubadora para o sucesso do negócio da empresa incubada conforme o grau de importância percebido.

\begin{tabular}{|c|c|c|c|c|c|}
\hline & 1 & \multirow[b]{2}{*}{2} & \multirow[b]{2}{*}{3} & \multirow[b]{2}{*}{4} & \multirow{2}{*}{$\begin{array}{c}\mathbf{5} \\
\text { Muito } \\
\text { importante }\end{array}$} \\
\hline & $\begin{array}{c}\text { Nada } \\
\text { importante }\end{array}$ & & & & \\
\hline $\begin{array}{l}\text { Infraestrutura (salas individuais e coletivas, laboratórios, auditório, biblioteca, } \\
\text { salas de reunião, recepção, copa, cozinha, estacionamento) }\end{array}$ & 0 & 1 & 1 & 1 & 8 \\
\hline Serviços básicos (telefonia e acesso à web, recepcionista, segurança, xerox) & 1 & 3 & 3 & 2 & 2 \\
\hline $\begin{array}{l}\text { Assessoria (gerencial, contábil, jurídica, apuração e controle de custo, gestão } \\
\text { financeira, comercialização, exportação) }\end{array}$ & 0 & 3 & 1 & 4 & 3 \\
\hline Qualificação (treinamento, cursos, assinaturas de revistas, jornais e publicações) & 0 & 0 & 4 & 3 & 4 \\
\hline $\begin{array}{l}\text { Network (contatos de nível com entidades governamentais e investidores, } \\
\text { participação em eventos de divulgação das empresas, fóruns) }\end{array}$ & 0 & 0 & 3 & 3 & 5 \\
\hline
\end{tabular}

A tabela 2 demonstra que o serviço considerado de extrema importância pela maioria das incubadas foi a infraestrutura, seguido do network. Esses resultados contrariam estudos realizados por Barbosa e Hoffmann (2013) em que a infraestrutura não é o serviço considerado mais importante pelos empresários das incubadas. Ainda, nesse sentido, no estudo realizado por Serra et al. (2010), é ressaltado que as incubadoras que oferecem mais serviços agregados, além da tradicional infraestrutura, são as que há maior procura e disputa pela participação das empresas no processo de seleção. Os gestores das incubadas também avaliaram os resultados das ações de cooperação com a universidade/faculdade e foram questionados se houve sucesso ou insucesso nessas ações, conforme apresentado no quadro 2. 
Quadro 2: Percepções dos gestores das incubadas referente aos resultados das ações de cooperação com a universidade/faculdade.

\begin{tabular}{|c|l|}
\hline Identificação & \multicolumn{1}{c|}{ Resposta da questão número 13 } \\
\hline Incubada 1 & Sucesso preeminente. \\
\hline Incubada 2 & Não houve sucesso, pois não existe cooperação entre startup e universidade. \\
\hline Incubada 3 & Sucesso, pois a universidade nos dá suporte para crescer nos mercados que estamos inseridos. \\
\hline Incubada 4 & Não é possível avaliar no momento. \\
\hline Incubada 5 & $\begin{array}{l}\text { Sucesso, já estamos fornecendo algum serviços para a Universidade e atingindo clientes por indicação } \\
\text { da Universidade. }\end{array}$ \\
\hline Incubada 6 & $\begin{array}{l}\text { Os resultados são positivos. O projeto ainda é inicial, porém já foi incrementado e o resultado futuro é } \\
\text { promissor. }\end{array}$ \\
\hline Incubada 7 & Por enquanto não consigo responder com convicção. \\
\hline Incubada 8 & $\begin{array}{l}\text { Houve sucesso, pois teve harmonia nas soluções. De nossa parte aprendemos muito com a Incubadora } \\
\text { e fizemos networking com diversas empresas. Capacitamos alunos, pelos quais foram chamados por } \\
\text { outras empresas e ficamos com aluno que melhor apresentou resultados. }\end{array}$ \\
\hline Incubada 9 & Até o momento só houve sucesso. \\
\hline Incubada 10 & Nós utilizamos somente treinamentos e consideramos bom. \\
\hline Incubada 11 & $\begin{array}{l}\text { Consideramos o projeto um sucesso até o presente momento, tendo em vista que a incubadora facilita } \\
\text { muito o acesso a qualificação dos processos de gestão e ao networking. }\end{array}$ \\
\hline
\end{tabular}

Conforme as respostas dos gestores das empresas incubadas, 8 das 11 empresas informaram que os resultados das ações de cooperação com a universidade/faculdade foram positivos e ressaltam que o papel da universidade serve como suporte para o crescimento, bem como a possibilidade de qualificação e networking. Ainda nessa questão, 2 empresas informaram que ainda é cedo para avaliar as ações, pois foram incubadas no ano de 2014.

Por fim, somente 1 empresa informou que não houve sucesso pois não existe cooperação entre startup e universidade. Consoante a isso, os estudos realizado por Barbosa et al. (2013) e Salvador et al. (2009) verificaram que o acesso a outras empresas (networking) e capacitação do perfil profissional foram tópicos considerados muito importantes para os empresários. Ainda, foram questionados se a cooperação entre a universidade/faculdade e a indústria é benéfica para ambas as partes, conforme o quadro 3.

Quadro 3: Percepções dos gestores das incubadas referente ao benefício da cooperação entre a universidade/faculdade e as empresas

\begin{tabular}{|c|l|}
\hline Identificação & \multicolumn{2}{|c|}{ Resposta da questão número 14 } \\
\hline Incubada 1 & Sim. Possibilita o sucesso da empresa e prestigia a universidade. \\
\hline Incubada 2 & Acredito que pode ser benéfica, mas, em nossa área de atuação, talvez precise ser melhor trabalhada. \\
\hline Incubada 3 & Sem dúvida, pois aumenta a aplicação de melhoria continua e todos saem ganhando. \\
\hline Incubada 4 & Sim. Porque criar oportunidades. \\
\hline Incubada 5 & Sim, pois temos a pesquisa na Universidade e uma indústria atrasada tecnologicamente no Brasil. \\
\hline Incubada 6 & NÃO HOUVE RESPOSTA. \\
\hline Incubada 7 & Sim. \\
\hline Incubada 8 & $\begin{array}{l}\text { Acredito que sim. Pois, ambos aprendem os processos e dificuldades em fazer a empresa evoluir. Antes } \\
\text { era uma semente, agora é uma realidade que está evoluindo pra buscar cerne e novos recursos do } \\
\text { governo federal para pesquisa. }\end{array}$ \\
\hline Incubada 9 & NÃO HOUVE RESPOSTA. \\
\hline Incubada 10 & NÃO HOUVE RESPOSTA. \\
\hline Incubada 11 & Sim, porque gera inovação para a universidade, crescimento sustentável para a empresa incubada. \\
\hline
\end{tabular}

A última questão do questionário avaliou os resultados das ações de cooperação com a universidade/faculdade. Um total de 7 gestores das empresas incubadas responderam que acreditam que a cooperação entre a universidade/faculdade é benéfica às empresas, pois possibilita o sucesso da empresa e também o prestígio da IES, corroborando com o estudo realizado por Raupp et al. (2006) que verificou que o suporte oferecido pelas incubadoras contribuem para potencializar as características empreendedoras nas 
empresas incubadas. Ainda, relatam que todos os dois atores, incubadoras e incubadas, ganham com essas ações, geram inovação à IES e há crescimento sustentável para a empresa incubada através da melhoria contínua.

\section{CONCLUSÕES}

Os resultados obtidos mostram que todas as incubadoras possuem gestão da performance, oferecem serviços base, técnicos, de gestão, estratégicos e realizam seleção de empresas incubadas. Ainda, os fatores percebidos pelas incubadoras como importantes para a performance das incubadas são a qualificação e o network, o que confirma com os achados do estudo realizado por Salvador et al. (2009). Foi possível identificar que as incubadas são da área de tecnologia e há pouco tempo estão no processo de incubação, sendo que o motivo que fez com que houvesse a participação nesse processo é de usufruir do espaço alugado e de demais ajudas. As incubadas citam que para que haja o sucesso nas ações com as universidades é necessário qualificação e network, percepção semelhante aos gestores das incubadoras.

Com isso, é possível perceber a importância das incubadoras no que se refere ao suporte às novas empresas e como isso impacta no desenvolvimento da economia, da mesma maneira que Raupp et al. (2006) apresentam em seu estudo. Ainda, a pesquisa mostra que foi possível compreender tanto a visão dos gestores das incubadoras, quanto dos gestores das incubadas, para que se saiba no que investir, como se comunicar e o que oferecer. Também é possível verificar como as incubadoras disponibilizam seus serviços e se comportam de forma parecida mesmo que estejam localizadas em diferentes IES, diferentes regiões do estado e em diferentes culturas. Quanto às incubadas, percebe-se uma similaridade das percepções do que é importante para o crescimento das empresas, mesmo que o processo de incubação seja recente para todas as empresas pesquisadas.

Como limitações da pesquisa, podemos citar o número de incubadoras e incubadas que responderam ao questionário, bem como o tempo para a coleta dos dados. Identificou-se também dificuldade em encontrar contatos atualizados das empresas incubadas que estão localizadas em outras cidades. Como implicação teórica percebe-se que o tema é bastante amplo em contextos diferentes e possibilitará a disseminação de conhecimento a respeito de incubadoras e incubadas ligadas à instituição de ensino superior do Rio Grande do Sul, além de fomentar ainda mais outras pesquisas.

Como implicação gerencial percebe-se que é relevante identificar quais são os serviços prestados pelas incubadoras e quais serviços são efetivamente considerados importantes para que as empresas optem pelo processo de incubação vinculado à IES, orientando-os a melhorar seus processos internos desde a divulgação para a incubação até os serviços prestados durante o processo de incubação.

Para pesquisas futuras nessa área, sugere-se que seja realizada uma pesquisa de natureza quantitativa para que se identifiquem quais são as relações e influências das variáveis identificadas nesse estudo. Além disso, sugere-se que seja realizada entrevista diretamente com os funcionários das empresas incubadas para identificar se assim como os gestores, os serviços oferecidos são percebidos e considerados importantes de maneira semelhante ou se há visões diferentes. 


\section{REFERÊNCIAS}

AHMAD, A. J.; INGLE, S.. Relationships matter: case study of a university campus incubator. International Journal of Entrepreneurial Behaviour \& Research, v.17, n.6, p.626-644 2011.

ANDRADE, T.. Inovação e ciências sociais: em busca de novos referenciais. Revista Brasileira de Ciências Sociais, v.20, n.58, p.145-211, 2005.

ANPROTEC. Associação Nacional de Entidades Promotoras de Empreendimentos Inovadores. Panorama 2007. Brasília: ANPROTEC, 2015.

BAÊTA, A. M. C.; BORGES, C. V.; TREMBLAY, D. G.. Empreendedorismo nas incubadoras: Reflexões sobre tendências atuais. Comportamento organizacional e gestão, v.12, n.1, p.7-18, 2006.

BARBOSA, L. G. F.; HOFFMANN, V. E.. Incubadora de empresas de base tecnológica: percepção dos empresários quanto aos apoios recebidos. Revista de Administração e Inovação, v.10, n.3, p.208-229, 2013.

BOLLINGTOFT, A.. The bottom-up business incubator: leverage to networking and cooperation practices in a selfgenerated, entrepreneurial enabled environment. Technovation, v.32, n.5, p.304-315, 2012.

BRASIL, M. V. O.; NOGUEIRA, C. A. G.; FORTE, S. H. A. C.. Schumpeter e o desenvolvimento tecnológico: uma visão aplicada às pequenas e médias empresas. Revista de Ciências da Administração, v.13, n.29, p.38-62, 2011.

BRASIL. Ministério da Ciência e Tecnologia. Manual para a Implantação de Incubadoras de Empresas. Brasília: MCT, 2000.

BRUNEEL, J.; RATINHO, T.; CLARYSSE, B.; GROEN, A.. The evolution of business incubators: comparing demand and supply of business incubation services across different incubator generations. Technovation, v.32, n.2, p.110-121, 2012.

CHESBROUGH, H.; VANHAVERBEKE, W.; WEST, J.. Open Innovation: Researching a New Paradigm. USA: Oxford University Press, 2006.

COOPER, A. C.. Spin-offs and technical entrepreneurial. IEEE Transfer enginneering Management, v.18, n.1, p.2-6, 1971.

DORNELAS, J. C. A.. Empreendedorismo corporativo: Conceitos e aplicações. Revista de Negócios, v.9, n.2, p.8182, 2004.

DRUCKER, P. F.. Innovation and entrepreneurship. New York: Harper \& Row, 1985.

ENGELMAN, R.; FRACASSO, E. M.; BRASIL, V. S.. A qualidade percebida nos serviços de incubação de empresas. In: ENCONTRO NACIONAL DA ASSOCIAÇÃO NACIONAL DE PÓSGRADUAÇÃO E PESQUISA EM ADMINISTRAÇÃO. Anais. São Paulo: ANPAD, 2009.

FINER, B.; HOLBERTON, P.. Incubators: there and back. Journal of Business Strategy, West Yorkshire, v.23, n.3, p.2325, 2002.
GIBBS, G.. Análise de dados qualitativos. Porto Alegre: Bookman, 2009.

GIL, A. C.. Como elaborar projetos de pesquisa. São Paulo: Atlas, 2002.

GIL, A. C.. Métodos e técnicas de pesquisa social. São Paulo: Atlas, 2008.

GUIMARÃES, C. L.; SENHORAS, E. M.; TAKEUCHI, K. P.. Empresa júnior e incubadora tecnológica: duas facetas de um novo paradigma de interação empresa-universidade. In: SIMPÓSIO DE ENGENHARIA DE PRODUÇÃO. Anais. Bauru: UNESP, 1999.

HISRICH, R.; PETERS, M.. Empreendedorismo. Porto Alegre: Bookmann, 2004.

KILCREASE, K. M.. Multi-factor assessment of service delivery in business incubators: perspectives from incubators tenants. The Journal of Applied Management and Entrepreneurship, v.16, n.2, p.80-95, 2011.

LACERDA, A. C. D.; REIS, D. R. D.; PERINI, F. A.; CARVALHO, H. G. D.; CAVALCANTE, M. B.; BRUEL, S.. Tecnologia: estratégia para a competitividade. São Paulo: Nobel, 2001.

LANZILLOTTI, R. F.. Schumpeter, product innovation and public policy: the case of cigarettes. In: Entrepreneurships, the New Economy and Public Policy, Berlim, p.11-32, 2005.

LEIFER, R.; MCDERMOTT, C. M.; O`CONNOR, G. C.; PETERS, S.; RICE, M.; VERYZER, R. W.. Radical innovation: how mature companies can outsmart upstarts. Cambridge: Harvard Business Scholl Press, 2000.

MARQUES, J. P. M. M.. As incubadoras de empresas com ligações à Universidade e a cooperação Universidade Indústria: o caso de Portugal. Tese (Doutorado) Universidade de Aveiro, Aveiro, 2005.

MELO, M. C. O. L.; MUYLDER, C. F.; LOPES, A. L. M.; CASSINI, M. R. O. L.; RABELO, N. G.. O empreendedorismo e o papel das incubadoras para as empresas graduadas de base tecnológica da região metropolitana de Belo Horizonte. In: SEMINÁRIOS EM ADMINISTRAÇÃO, 12. Anais. São Paulo: EDUSP, 2009.

MORAIS, E.. Manual de Acompanhamento e auto-avaliação de incubadoras e empresas incubadas. Brasília: ANPROTEC, 1997.

MORRIS, M. H.. Entrepreneurial intensity: sustainable advantages for individuals, organizations, and societies. London: Quorum Books, 1998.

PRODANOV, C. C.; FREITAS, E. C.. Metodologia do Trabalho Científico: métodos e técnicas da pesquisa e do trabalho acadêmico. 2 ed. Novo Hamburgo: Editora Feevale, 2013.

QIAN, H.; HAYNES, K. E.; RIGGLE, J. D.. Incubation push or business pull? Investigating the geography of U.S. business incubators. Economic Development Quarterly, v.25, n.1, p.79-90, 2011. 
RATINHO, T.; HENRIQUES, E.. The role of science parks and business incubators in converging countries: evidence from Portugal. Technovation, v.30, n.4, p.278-290, 2010.

RAUPP, F. M.; BEUREN, I. M.. O suporte das incubadoras brasileiras para potencializar as características empreendedoras nas empresas incubadas. Revista de Administração, v.41, n.4, p.419-430, 2006.

RIBEIRO, S. A.; ANDRADE, R. M. G.; ZAMBALDE, A. L.. Incubadoras de empresas, inovação tecnológica e ação governamental: o caso de Santa Rita do Sapucaí (MG). Cadernos EBAPE. BR, v.3, p.1-14, 2005.

SALVADOR, A. L.; TUTIDA, L.; CERETTA, G. F.. Incentivos concedidos por incubadoras e suas influências no desempenho de MPES de base tecnológica: $O$ caso do hotel tecnológico da UTFPR de Cornélio Procópio-PR. Revista Diálogos \& Saberes, v.5, n.1, 2009.

SCHUMPETER, J. A.. Teoria do desenvolvimento econômico. Cambridge: Harvard University, 1959.
SCHWARTZ, M.; HORNYCH, C.. Specialization as strategy for business incubators: an assessment of the Central German Multimedia Center. Technovation, v.28, n.7, p.436-449, 2008.

SERRA, B.; SERRA, F. R.; FERREIRA, M. P.; FIATES, G. G.. Fatores Fundamentais para o desempenho de incubadoras de base tecnológica. Revista de Administração e Inovação, v.8, n.1, p.221-247, 2011.

SOMSUK, N.; WONGLIMPIYARAT, J.; LAOSIRIHONGTHONG, T.. Technology business incubators and industrial development: resource-based view. Industrial Management \& Data Systems, v.112, n.2, p. 245-267, ago. 2012.

WIGGINS, J.; GIBSON, D.. Overview of US incubators and the case of the Austin Technology Incubator. Journal Entrepreneurship and Innovation Management, v.3, n.1, p.56-66. 2003. 